\title{
Ungrateful citizens? Women's rights policies in Zapatero's Spain
}

Kerman Calvo* and Irene Martín

* Authors are listed in alphabetical order and share responsibility.

http://dx.doi.org/10.1080/13608740903503860

Publicado como : Kerman Calvo and Irene Martín (2009): "Ungrateful citizens? Women’s rights policies in Zapatero’s Spain”, South European Society and Politics, 14 (4): 487-502.

\begin{abstract}
Women attracted the lion's share of government initiatives in the area of citizenship rights during the government of Zapatero (2004-08) in Spain. Highlights of these efforts were policies on gender violence and gender equality. We analyze these policies in terms of their scope, people's awareness, implementation and the level of support from other parties in the opposition. We then look for the possible impact of these policies on the gender gap in political interest and on voting orientations. We find only a slight impact on women's voting patterns from IU to PSOE.
\end{abstract}

Keywords: Political interest; Gender gap; Politics of presence; Empowerment; Zapatero’s Spain.

\section{Bio}

Kerman Calvo (MA, Juan March Institute, Madrid; PhD, Essex) is a García Pelayo research fellow at the Spanish Centre for Constitutional Studies. He has held teaching and research positions at the universities Pompeu Fabra in Barcelona, Open University of Catalonia, Carlos III in Madrid and Essex. He has published in the areas of gay and lesbian politics and religiosity and politics.

Irene Martín (MA, Juan March Institute, Madrid; PhD, Universidad Autónoma de Madrid) is lecturer in the Department of Political Science at UAM. She has been a visiting fellow at Princeton University and at the University of Athens. Her main topics of research and publications have dealt with political involvement in Southern Europe, young people and politics, and education for citizenship. 
Plenty of attention was paid during José Luis Rodriguez Zapatero’s first term as Prime Minister (2004-08) to the extension of citizenship rights to oppressed groups in general, and to women in particular. In what Maravall (2009, pp. 264-266) defined as a 'rediscovery of liberalism', Zapatero promoted a set of new policies that pivoted around a common principle: 'let those who have suffered become equal'. ${ }^{1}$ Observers and students of Spanish politics have seen a connection between the introduction of a new agenda on citizenship and social rights by the Partido Socialista Obrero Español (PSOE, Spanish Socialist Party) and Zapatero’s assimilation of Philip Pettit’s ideas on 'civic republicanism' (Calvo 2009). This implies 'on the one hand, a solid ideal based on giving people power and social protection and, on the other, an ideal of civic control of government'; it also requires a citizenry 'that is relentlessly involved' (Pettit 2008, pp. 156, 181). Political involvement, however, has always been considered the fly in the ointment of Spain's remarkable democratic consolidation. High levels of political disaffection, including extremely low levels of political interest in comparative terms, are seen by many as one of the most unfortunate legacies of the Spanish transition towards democracy in the mid-1970s. Overcoming these limitations requires improving the quality of Spanish democracy, including the introduction of new incentives that could re-orient citizens’ psychological orientations towards politics. Rather than revisiting old formulas based on institutional politics and elite arrangements, a revamped effort to engage with a genuine 'second transition', seems bound to focus on citizens' values and attitudes. This would create the conditions for active and effective participation in politics at the mass level.

How apt are citizenship policies to foster interest in politics? Are Zapatero's initiatives in the areas of civil rights, welfare reform and democratic renewal contributing to a larger process of democratic maturation that could be conducive to democratic deepening, or what some have 
referred to as a 'second transition'? In this contribution we focus on women and discuss whether resonant policies that extended civil and social rights brought about changes in political attitudes and behaviour. First, we explore in some detail women’s policies in Zapatero’s Spain, paying close attention to the issues of gender violence and equality. We show that powerful institutional constrains have severely limited the effects of these policies. Second, we discuss women's political attitudes and voting patterns in light of these policy developments. In particular we focus on interest in politics, investigating connections between changes in this attitude and policy developments. Also, we analyse if these policy initiatives led to a greater predisposition among women to vote for the PSOE.

Our strategy in this contribution is in line with the existing literature on the connections between policy making and women's political behaviour. According to some of this literature the greater the number of women in politics, the more they will trigger women's political involvement (Campbell \& Wolbrecht 2006; Dovi 2002). Moreover, the impact of presence seems to be mediated by the degree of visibility (i.e. the level of the office held or aimed at) and viability (i.e. the real possibilities of reaching those aims) (Atkeson 2003). In line with this previous research, we analyze if women's political interest and their propensity to vote for PSOE increased between a point prior to the above mentioned policies and two points after they had been passed: immediately after some of the most emblematic ones had passed and the 2008 elections.

\section{A New Style of Women's Policies}

During the Zapatero government, parliament enacted a wealth of policies that touched on the rights and welfare entitlements of women. Of course, public policies for women had existed in 
Spain for quite some time (Valiente 1996). What sets Zapatero’s policies apart is the fact that these are mostly rights policies: they activate the citizenship status of women to a degree, resonance and political saliency never achieved before. For instance, the so-called dependency law, passed in 2006, introduced a new range of benefits in the area of social and community care that paid close attention to the burden that caring imposes on women. Also, the new education law, also passed in 2006, introduced a new compulsory subject on civic education that engages with issues of equality, gender, difference and diversity.

Violence and equality, however, were the areas where concerns about female citizenship gained a clearer momentum. ${ }^{2}$ The new policy on gender violence, passed in 2004, frames violence as located at the epicentre of a complex web of social, economic and cultural exchanges of power between men and women. The new equality law, passed in 2007, represents an ambitious effort to regulate sexual harassment and discrimination in employment. The policy engages with positive discrimination as well by introducing quotas for women in electoral lists and in the composition of the governing bodies of large companies. Lastly, Zapatero also paid considerable attention to the question of female presence. In March 2004 the appointed cabinet had the same number of female and male ministers. Similarly significant was the appointment, for the first time in Spanish history, of a woman as deputy prime minister.

The bearing of women's rights policies on their political interest and behaviour is mediated by several factors. Four of which are discussed in this section: first, the scope of rights and whether large classes of women feel affected by the new policies; second, awareness, as unknown policies are unlikely to shape voters' preferences; third, implementation, as policies perceived as badly implemented are likely to leave voters' choices unscathed; lastly, political 
agency, as voters are likely to respond to how political parties frame issues, entitlements and rights.

\section{Scope}

The policies on violence and equality set out to bring about significant changes in the legal entitlements of women. The law on violence does this, on the one hand, by strengthening security measures and, on the other, by giving women remedial entitlements in the areas of social policies and housing intended to help victims of violence set a new life course (Coll-Planas 2008; Osborne 2008, 2009). The new law polemically restricted its scope to the problem of male violence toward women only. According to the law, women who suffer from sexist violence have a host of new entitlements in the areas of housing, welfare, labour law and criminal and health assistance. For instance, victims of violence are expected to be given priority in the competition for public housing. In the area of criminal law, it introduced new legal mechanisms to enhance the safety of threatened women, including more powerful and efficient restriction orders for perpetrators of violence. More victims of violence are now entitled to free legal counselling. A significant transformation in the organisation of criminal justice also occurred as a consequence of this policy: 17 specialized courts were created which are solely concerned with gender violence and another 417 judicial sections are also primarily entrusted with dealing with these cases even if, in this case, judges may also hear cases of a different nature (Consejo General del Poder Judicial 2008). Initially, 50 prosecutors were assigned to these new courts, yet the number is bound to grow in the forthcoming years. It must be stressed that the law defines generic entitlements that, however, are to be provided by regional and local governments. Some 
central government funding has been earmarked to assist sub-national governments (Ministerio de Igualdad 2008, pp. 27-29).

While the law on violence engages with basic civil rights, the equality law deals with some important aspects of women’s political and social citizenship (López 2007). The law’s chief aim was to promote gender equality in all walks of life, including working conditions and the representation of women in elected bodies (at all state levels) and in the governing bodies of large companies. According to these grand ambitions, the equality law works at a threefold level (López 2007). First, the law clarifies the meaning of discrimination and harassment. This is meant to facilitate judicial redress (Pérez del Río 2007, p. 223). In doing so the Spanish government is adopting two European Union (EU) directives: Directive 2002/73/EC on the implementation of the principle of equal treatment for men and women regarding access to employment, vocational training and promotion, and working conditions; and Directive 2004/113/EC implementing the principle of equal treatment between men and women in the access to and supply of goods and services. Second, the law has an affirmative action dimension in so far as new obligations are introduced for public bodies and institutions to develop equality plans and initiatives regarding the equal treatment of men and women. Third, and perhaps most importantly, the law introduces positive discrimination as a legitimate policy priority.

The equality policy also builds on initiatives at the international and sub-national levels to introduce quotas for the representation of women. It establishes a route map for gender equality in the governing bodies of large companies: companies with more than 50 employees are requested to proceed with a ten per cent annual increase in the presence of women in those bodies. The target is that by 201540 per cent of these positions will be held by women. Note that the law does not include enforcement mechanisms or penalties if these targets are not met; 
companies are now simply expected to draft unbinding equality action plans. In the area of political representation, political parties are now required to assure that neither sex has a representation higher than 60 per cent or lower than 40 per cent of candidate positions on election lists. Regional electoral laws are also allowed to set a more equal gender balance when it comes to elections at that level. ${ }^{3}$ The equality law gives political parties a great degree of liberty to decide on the placement of candidates on the list (provided that at least two women are included in every group of five candidates), and also on the selection of candidates for the top positions on the list. ${ }^{4}$ Unlike the French situation, where breaches of quota provisions are met with fines, in Spain a failure to comply with quota instructions results in the annulment of the concerned list.

\section{Awareness}

Available data suggest that Spanish women were generally aware of the existence of both these laws. By December 2007, virtually 90 per cent of the population 'had heard of the existence' of the equality law (which had been passed at the beginning of that year). There were no gender differences in this data. Societal awareness about the equality law was thus very high and clearly superior to that of the dependency law (75 per cent of both sexes). ${ }^{5}$ The law against gender violence was passed in 2004: at the end of 2005 only 73 per cent of women declared to have heard of this law. ${ }^{6}$ Awareness, however, does not mean high expectations. Data reveal that more than 50 per cent of women considered the equality law to be a 'not very effective means to achieve goals' (only 31 per cent of men aligned with this pessimistic mood). In 2005, in a differently worded question, out of the roughly 75 per cent of interviewees who declared to have 
an opinion, the opinions for and against the effectiveness of the law were evenly split (with no meaningful gender differences).

\section{Implementation}

The policies discussed in this section constitute a rather ambitious package of citizenship-making political initiatives. However both policies call for considerable effort in terms of budget and intergovernmental coordination as in Spain social service provision is the purview of regional and local governments. Existing evaluations of the law on violence cast a very dark picture over its implementation and overall impact. In what appears to be the most comprehensive and detailed assessment, the Spanish chapter of Amnesty International claimed that 'the law has made a weak impact on the pathway of those women surviving gender violence' (Amnistía Internacional 2008, p. 4). Several of the provisions of the law are simply still inoperative, while lack of coordination is resulting in gross differences across regions in terms of levels of protection (Amnistía Internacional 2007; Osborne 2008). The law has not been effective at reducing killings; the number of women killed by their male partner while they were protected with a restriction order increased from 20 per cent in 2005 to 30 per cent in 2007 (Amnistía Internacional 2008, p. 15). The same holds true for those women actually filing criminal complaints against their abusers: the number of these women ultimately killed also rose between 2005 and 2008. Scholarly studies and research reports lament that the lack of coordination with regional authorities is resulting in gross territorial differences in the level and quality of services put at the disposal of victims. Also, some of the programs outlined in the law on violence are yet to be developed, including training and service protocols at the National Health Service. While the creation of specialized courts and the heightening of punishment for perpetrators promptly 
followed the passing of the law, observers identified a great number of obstacles that diminish the chances of women getting speedy and fair judicial rulings (Bustelo \& Lombardo 2007). Amnesty International denounced that virtually half the women killed in 2007 could not get free legal counselling.

The implementation of the equality law is also fraught with difficulties. Some of them are again related to the decentralized nature of the Spanish state: while rights-based policies remain the exclusive province of the central government, the obligatory participation of several levels of government in the definition of new welfare entitlements severely hinders the short-term effectiveness of this type of initiative. However, the law seems to have stumbled in the area where it was most resonant, that is, that of electoral quotas. In terms of actual improvements of political representation, the new equality law has had mixed results. At the local level, for instance, the mandated increase in the number of female candidates seems to have effectively raised the number of female candidates and representatives (Verge 2008). According to official election data, the percentage of women represented in local assemblies in 2007 was 39.7 per cent, as against 32.3 per cent in 2003 (Field 2009, p. 157). Parity, however, has not yet been achieved. At the national level, while an increase in the number of female members of the upper chamber was registered after the general elections of 2008, from 26 to 32 per cent, the number of female members of the lower chamber in fact decreased, from 127 to 126 members (36 per cent). In an assessment of the electoral impact of the equality law, Martínez and Calvo (2010 forthcoming) argue that the 'letter' of the law was respected by all political parties. Accordingly, the rules related to balancing the composition of party lists in terms of gender have significantly increased the number of women candidates. In the case of the PSOE, this has translated into a number of representatives that falls within the legal definition of parity (i.e., no less than 40 per 
cent and no more of 60 per cent of candidates for any of the two sexes): after the 2008 general elections 43 per cent of the members of the Socialist parliamentary group were women. Note, however, that this was not an increase: in 2004 women represented 46 per cent of this group. Having been internally governed by voluntary quotas since the late 1980s, the PSOE had no major problems meeting the legal standard that, in reality, was simply reflecting the daily life of the party. The PP, however, did not convert an egalitarian number of candidates into an egalitarian number of representatives. In 2008 female candidates represented only 30 per cent of the members of the parliamentary group. This reflects party decisions with regard to the positioning of women on electoral lists. The PSOE adopted a system (mostly in the large districts) by which female and male candidate alternate positions (with the top of the list most commonly given to a male candidate). However, the PP does not allow enough women to occupy any of the top three positions on most of the lists. This results in many conservative female candidates occupying ‘unsafe’ positions.

\section{Agency}

Unlike other policies with a civil rights ringtone passed between 2004 and 2008, the plans for a comprehensive policy to protect and empower women who suffered from violence were met with general applause. The exception to this was the limitation to a specialized form of violence, namely violence exercised by men against women. Commentators, nongovernmental organisations and some sectors of the women's and the lesbian, gay, bisexual and transgender social movements claimed, firstly, that violence also took place within same-sex couples, secondly, that women could also be perpetrators of violence and, lastly, that women can suffer from violence exercised by other members of the family unit (Amnistía Internacional 2007; 
Osborne 2008, pp. 115-117). In spite of the mounting evidence of implementation problems, the issue of violence has not been activated as a dividing issue between the PSOE and the PP. However, the Popular Party opposes state intervention in gender parity. It had already done so while in government by denouncing before the Constitutional Court gender parity electoral laws in autonomous communities (Martínez Alarcón 2008, p. 109; Verge 2008, pp. 128-129). A similar strategy was followed against the equality law. Contrary to the expectations of the PP, the Spanish Constitutional Court gave qualified support to positive discrimination policies. Business associations also opposed the sections of the equality law imposing quotas on business (Pérez del Río 2007, p. 233). In this case they succeeded in their quest, as the government finally trimmed down the law eliminating the penalties in those cases where companies failed to meet their legal obligations.

\section{Political Culture, Gender Differences and the Challenges of Democratic Deepening}

A number of reasons justify taking a closer look at political interest. A politically indifferent society could lead to easier political manipulation and to the questioning of democracy; political interest, as a sign of civic virtue, can contribute to the good functioning of institutions; political interest facilitates the processing of complex information as well as decision making and, in playing that role, it can be a substitute for high levels of education. In general, political interest is said to contribute to the formation of stable and coherent political opinions, as well as to political participation of several types (Martín 2004, pp. 9-14). Low levels of interest in politics in Spain have often been explained in culturalist terms. According to this argument, a long dictatorship that, unlike others of the time, followed strategies for political demobilisation and a historical background of recurrent clientelistic practices, corruption, democratic instability and civil wars 
rendered Spaniards culturally allergic to anything political (López Pintor 1982, p. 78; Montero, Gunther \& Torcal 1997).

Some authors contend that this classic culturalist approach to attitude formation that stresses historical legacies and the role of early socialization cannot explain changes in the short term, and have thus emphasized the capacity of political elites under extraordinary circumstances to reshape the political culture of society. According to this view, widespread political disaffection in Spain was critically reinforced - or even fostered anew - during the time of the transition to democracy. More specifically, it was the consequence, not of the past, but of deliberate attempts by the political protagonists of that political moment, to demobilise or, at least, 'not mobilise' for the good of consensus and a peaceful transition to democracy (Paramio \& Reverte 1980). A third line of argument points to the possibility that societies can change in ways that are not always foreseeable simply by looking at their past history or at the decisions taken during critical junctures. Individuals are rational beings that keep evaluating what happens in the political sphere and are susceptible to change at different moments of their life-cycle, thus leading to changes in political attitudes in the short term. In the case of political interest, in spite of it being, in general, a very stable attitude (Prior forthcoming) we find some examples where noticeable and rather consolidated changes in the levels of this political attitude have taken place within a short period time (Galais 2008; Martín 2004).

That women are less politically involved than men is a defining feature of the Spanish political cultural map (García \& Frutos 1999; Morales 1999, 2006; Uriarte 1997). Part of the explanation of the lower levels of political engagement of women lies in the fact that, on average, they have fewer resources (i.e. education, work) than men (Campbell \& Wolbrecht 2006, p. 234; van Deth \& Elff 2000, p. 7). This is evident in the youngest cohorts where, both in 
Spain and in other countries, the gap is notably smaller (García \& Frutos 1999; Hooghe \& Stolle 2004; van Deth \& Elff 2000). Differences in resources alone, however, do not explain away the gender gap (Atkeson \& Rapoport 2003; Bennett \& Bennett 1989; van Deth 2000; Verba, Burns, \& Schlozman 1997). In line with culturalist explanations, most of the literature suggests that gender differences in attitudes and behaviour are strongly connected with early socialization (Morales 1999).

\section{Policies That Create New Citizens?}

Using data from the Centro de Investigaciones Sociológicas (CIS, Centre for Sociological Research) we face a twofold task. In the first place, we test the strength of the gender gap in political interest: have levels of political interest among women become more similar to those of men after it became evident that women's empowerment was a priority in the government's agenda? Secondly, we compare the gender gap in voting before and after the 2004 elections; we do this by comparing both the decision to vote for the PSOE instead of voting for the PP and also the decision to vote for the PSOE instead of voting for the leftist alliance Izquierda Unida (IU, United Left). Have women become more prone to vote for PSOE instead of for each of the other two parties? We have built a pooled dataset by aggregating several surveys during the period 1989 to $2008 .^{7}$ This allows us to control for time effects in a more parsimonious fashion. For this purpose we have selected those surveys in which we can measure the impact of the gender gap on both political interest and voting, and control, at the same time, for other factors that could have also had an influence on both, such as age, education, religiosity and ideology.

The selection of surveys was conditioned by both the dependent and the independent variables in the model. Given the renewed intensity of the conflict between the government and 
the Catholic Church hierarchy, we selected those surveys that contained the same question on religiosity. 1989 is the year when this indicator first appeared in the CIS series of surveys. In 2004 that indicator was not included in any CIS survey. Electoral surveys carried out by other institutions also did not contain the question on religiosity, and their quality has proven highly problematic for drawing reliable conclusions (Martínez \& Calvo, forthcoming). For these reasons, most of the surveys selected are post-electoral studies and, therefore, the vote indicator measures vote intention and not vote in the past elections (except in 2008). However, for our purposes, having a measure for the election year 2004 is not essential. The surveys we have selected serve our purpose of comparing the impact of gender on our two dependent variables before and after the policies that addressed mainly women were passed. They also allow us to make sure that our conclusions are reliable, by showing if the results are peculiar to the period after the policies were passed, or if the same was observed at previous points in time since 1989.

First gender differences in political interest are explored (Table 1). As we expected, in line with the extensive literature on the political gender gap in political involvement, during this period women were, on average, less likely to be interested in politics than men. This is indicated by the negative sign of the coefficient of 'sex', which is statistically significant. But our main concern is whether differences in political interest between women and men increased or decreased after 2004 as a consequence of the transformation of their legal entitlements. If the policies aimed at the empowerment of women produced an increase in women's interest in politics, the gender gap should have declined. This finding would be confirmed in the second column of Table 1 by a negative sign of the interaction terms between sex and 2006 ('Sex*2006’) and sex and 2008 ('Sex*2008) when compared to the relationship between sex and interest in politics in 1989 (the reference category), since both in 2006 and 2008 at least some of 
the most emblematic policies of those mentioned above had already been passed. However, contrary to our expectations, we find no statistically significant gender differences in interest in politics between these two years and 1989. Zapatero’s efforts to improve the well-being of women do not seem to be bringing about direct and immediate effects on the political interest of women. A problem of lagged effects could be at stake, which would call for further research in the coming years.

\section{Insert Table 1}

While a general reaction from all women is not evident, it is still possible that empowering policies shape women's party preferences. In other words, instead of fostering a generalized interest in politics, initiatives such as the greater presence of women in politics and the laws extending women's rights could have resulted in greater support for the PSOE than for other parties. We explore this leg of the argument in the results presented in Table 2 . The models in Table 2 replicate those of Table 1 but in this case the dependent variable is vote. The first two models analyze only those who declared their intention to vote for PSOE and for PP while the third and fourth models analyze only those who had the intention to vote for PSOE and for IU during the same period. Our aim, once more, is to see whether women are more prone to vote for PSOE than for either of the other two parties, and whether the voting patterns of women as compared to men changed after 2004 in the expected direction.

\section{Insert Table 2}

The first model shows that, on average, during the period 1989-2008, women were more likely to vote for the PSOE than the PP, as indicated by the positive and statistically significant value of 'Sex'. We refer to this as a 'positive gender gap' in favour of PSOE. In this case, our expectation would be to see a growth in this gender gap meaning that in 2006 and 2008 women 
would become even more likely to vote for the PSOE than the PP compared to the previous years. If this were the case both interactions between sex and 2005 and sex and 2008 shown in the second model would be positive and significant. But, the findings do not confirm our expectations. In other words, it appears that the PSOE has not been able to attract the support of female PP voters. It is important to note that this resistance amongst PP female voters to switch their vote to PSOE takes place regardless of their ideology and of their degree of religiosity, which have been introduced as control variables in the models. That is to say, amongst PP female voters, both those with an extreme ideology and those that are more moderate did not change their vote in favour of the party that implemented policies that favoured women's position in society. The same can be said of religious and non-religious women voters of PP. In a way this is not in itself surprising: as argued before, the PP has refused to engage with a discourse on gender, challenging the need of policies, such as positive discrimination, that treat women as members of discriminated political minorities. The increased level of polarization between the PP and PSOE could have also acted as a deterrent for women that usually vote for PP to switch their vote to the PSOE.

The opposite, however, seems to be the case when we analyze if equality policies shaped the decision to chose the PSOE versus IU. The third column of Table 2 shows that, on average, being a woman or a man has not made it more likely to vote for one of these two parties in particular. However, the model represented in the last column in Table 2 gives us an indication that something important is actually happening: a negative and significant coefficient for the interaction between sex and 2005, just like in 1994, indicates that the gender gap in this case has actually decreased. It is not obvious how to interpret this finding: if, on average, women have not been more prone to vote for PSOE than IU, nor the other way round, how can we interpret this 
result? To answer this question we plot the expected probabilities of voting for PSOE versus IU amongst women and amongst men (Graph 1).

\section{Insert Graph 1}

The fact that, on average, there are no differences does not mean that women and men have never been different when facing this party choice. In 1989 women were a lot less likely to vote for PSOE and a lot more likely to vote for IU than men. In 1994 this gender gap had decreased (as indicated by the negative and significant effect of the interaction between sex and 1994), although it still existed. As the graph shows, in 2002 women's probability of voting for the PSOE instead of IU becomes equal to that of men and the gender gap disappears. In accordance with our expectations, in 2005 the trend reverses itself: women, for the first time during the period analyzed, become slightly more likely to vote for PSOE than for IU giving way to a further reduction of the gender gap (negative and significant effect of the interaction between sex and 2005 when compared to 1989). By the time the 2005 survey was done, the law against gender violence - one of the most daring policies aimed at empowering women, and also one of the measures that, at least at that time, counted on the almost unanimous support of all the political parties as well as of the Spanish society - had been passed in parliament a few months earlier. That the interaction coefficient is not significant in 2008 means that this tendency could be receding although, for the time being, as the graph shows, the probability of women and men voting for PSOE instead of IU are equal. Unlike in the case of electoral competition between PSOE and PP, in the case of PSOE and IU vote switching is obviously more likely, as it takes place within the same ideological field of the left. However, it should be noted that the gender gap had largely closed before 2004. 


\section{A Second Transition?}

The concern about women's full citizenship is still on Zapatero's mind. The victory in the 2008 general elections resulted in the recuperation of old plans to reform abortion legislation in Spain. If the announced bill successfully goes through the parliamentary process, Spanish women would be given abortion rights in line of those granted in most central and north European countries. Zapatero maintained the politics of presence by appointing in 2008 female ministers for the Defence and Economy portfolios. A (female) Minister of Equality was also appointed. However, neither the wealth of policy initiatives, nor the visibility granted to key female politicians seems to have been able to alter the gender gap in political interest: for the most part, women remain clearly less interested in politics than men, a (regretful) aspect of Spanish political culture that remains to be seriously addressed by political leaders and society as a whole. We have also considered party choice: an evaluation of public policies directed at women seems to have a reinforcing effect. Women who were already ideologically situated towards the left, and who were presented with a possibly difficult choice between IU and the PSOE might have come to see equality policies as the reason to tip the balance in favour of the latter over the former. Equality policies, however, are unlikely to trigger major shifts in voting behaviour.

A connection might have manifested between public polices and political attitudes. However, citizenship policies on behalf of Spanish women have not brought about changes of this sort. Why is this so? In the first place, we face a lagged effects problem. These policies are simply very recent and might need a longer period of time to bring about significant changes in political attitudes and voting patterns. Second, most of the policies discussed in this work have not been properly implemented. When expectations are generated but policies do not deliver, the effect might in fact be that of further disaffection with politics. We still lack surveys on citizens' 
evaluations of these policies; this information would be of unquestionably great help to ascertain if implementation is in fact to blame for the poor relationship found between policies, on the one hand, and political interest and vote orientations, on the other. Many more women are now visible in politics in Spain, and some of them occupy some of the highest positions in government. However, either they have not been elected directly by voters, or, when they have been elected, they formed part of a party list where individual candidates are not particularly visible. This could explain why, as our results imply, the visibility of women in politics has not had as clear of an impact in Spain after 2004 as in other countries (Campbell \& Wolbrecht 2006).

This brings us to the debate on a Spanish second transition; an attractive idea widely used among politicians, journalists and scholars alike to address the seemingly long list of 'must do' reforms of the Spanish democratic system to strengthen its quality and functioning (The Economist 2004). Our work suggests that such a process of change needs to be observed at a twofold level. There is a first area in which we can talk of policy change. The lack of recognition of citizenship rights devalues the quality of any democratic regime, and, accordingly, Zapatero’s civil rights agenda can be praised for including previously marginalised communities into the Spanish democratic political project. Emulating the defining characteristics of the transition process in the 1970s, one could speak of a second transition that has been successful in bringing about change at some institutional and policy levels. However, is Zapatero the architect of a transition process that creates better citizens? This second level of analysis engages with policy consequences and citizens’ responses. Our work suggests that Spanish political culture remains impervious to policy influences that would be conducive to a more involved style of democratic citizenship. Political disaffection is an enduring characteristic of Spanish political culture that conveys the image of a widening gap between increasingly isolated politicians and a massively 
disinterested citizenry. We see this to be a problem in need of bold initiatives by political and social elites and, especially so, when having women in mind. 


\section{References}

Amnistía Internacional (2007) 'Pongan todos los medios a su alcance, por favor. Dos años de ley integral contra la violencia de género’, available online at: http://prevencionviolenciagenero.com/archivos/InformeAI.pdf

Amnistía Internacional (2008) ‘Obstinada realidad, derechos pendientes tres años de la ley de medidas de protección integral contra la violencia de género’, available online at: http://www.es.amnesty.org/

Atkeson, L.R. (2003) 'Not all cues are created equal: the conditional impact of female candidates on political engagement', Journal of Politics, vol. 65, no. 1, pp. 1040-1061.

Atkeson, L.R. \& Rapoport, R.B. (2003) 'The more things change the more they stay the same: examining gender differences in political attitude expression, 1952-2000’, Public Opinion Quarterly, vol. 67, no. 1, pp. 495-521.

Bennett, L.L.M. \& Bennett, S.E. (1989) 'Enduring gender differences in political interest - the impact of socialization and political dispositions', American Politics Quarterly, vol. 17, no. 1 , pp. $105-122$.

Bustelo, M. \& Lombardo, E. (2007) Políticas de igualdad en España y en Europa, Ediciones Cátedra, Madrid.

Calvo, K. (2009) ‘Calidad de la democracia, derechos civiles y reforma de la política’, in La España de Zapatero. Años de cambio, 2004-2008, eds A. Bosco \& I. Sánchez-Cuenca, Editorial Pablo Iglesias, Madrid, pp. 205-227.

Campbell, D.E. \& Wolbrecht, C. (2006) 'See Jane run: women politicians as role models for adolescents', The Journal of Politics, vol. 68, no. 2, pp. 233-247. 
Coll-Planas, G. et al (2008) 'Cuestiones sin resolver en la ley integral de medidas contra la violencia de género: las distinciones entre sexo y género, y entre violencia y agresión’, Papers: Revista de Sociología, no. 87, pp. 187-204.

Consejo General del Poder Judicial (2008) ‘La justicia dato a dato 2008’, available online at: $\underline{\text { www.poderfudicial.es }}$

Dovi, S. (2002) 'Preferable descriptive representatives: will just any woman, black, or latino do?' American Political Science Review, vol. 96, no. 4, pp. 729-743.

The Economist (2004) ‘The second transition’, 24 June.

Field, B.N. (2009) 'The parliamentary election in Spain, March 2008', Electoral Studies, vol. 28, no. 1, pp. 155-158.

Galais, C. (2008) ‘ ¿Socialización o contexto? La implicación política subjetiva de los españoles (1985-2006)’, Unpublished Thesis, Universidad Pompeu Fabra, Barcelona.

García, J.J. \& Frutos, L. (1999) ‘Mujeres, hombres y participación política. Buscando las diferencias’, Revista Española de Investigaciones Sociológicas, no. 86, pp. 307-329.

Hooghe, M \& Stolle, D. (2004) 'Good girls go to the polling booth, bad boys go everywhere: gender differences in anticipated political participation among American fourteen-yearolds’, Women \& Politics, vol. 26, no. 3, pp. 1-23.

López, J. (2007) ‘Los principios rectores de la LO 3/2007 sobre igualdad efectiva entre mujeres y hombres a la luz de las estrategias de "gender mainstreaming” y “empowerment”, Revista del Ministerio de Trabajo e Inmigración, no. Extra 2, pp. 53-67.

López Pintor, R. (1982) La opinión pública española: del Franquismo a la democracia, Centro de Investigaciones Sociológicas (CIS), Madrid. 
Maravall, J.M. (2009) 'La socialdemocracia del gobierno de Zapatero’, in La España de Zapatero. Años de Cambio, 2004-2008, eds A. Bosco \& I. Sánchez-Cuenca, Editorial Pablo Iglesias, Madrid, pp. 249-277.

Martín, I. (2004) Significados y orígenes del interés por la política en dos nuevas democracias: España y Grecia, Instituto Juan March, Madrid.

Martínez Alarcón, M. (2008) ‘La ley orgánica para la igualdad efectiva de mujeres y hombres y la sentencia del tribunal constitucional 12/2008, de 29 de enero’, Revista de Estudios Políticos, no. 142, pp. 105-137.

Martínez, A. \& Calvo, K. (2010 forthcoming) ‘Un análisis del efecto de la ley de igualdad en la representación electoral, parlamentaria y en el comportamiento electoral de las mujeres en las elecciones generales de 2008’, Fundación Alternativas, Madrid.

Ministerio de Igualdad (2008) 'Evaluación de la ley orgánica 1/2004, de 28 de diciembre, de medidas de protección integral contra la violencia de género. Informe ejecutivo. Ministerio de Igualdad. 2008', available online at: $\underline{\text { www.migualdad.es }}$

Ministerio del Interior (2007) ‘Elecciones locales 2007. Impacto de la ley orgánica 3/2007, de 22 de marzo, para la igualdad efectiva de mujeres y hombres’, Ministerio del Interior, Madrid.

Ministerio del Interior (2008) ‘Elecciones a Cortes Generales 2008. Impacto de la Ley para la igualdad efectiva de mujeres y hombres’, Ministerio del Interior, Madrid.

Montero, J.R., Gunther, R. \& Torcal, M. (1997) 'Democracy in Spain: legitimacy, discontent, and disaffection', Studies in Comparative International Development, vol. 32, no. 3, pp. 124-160. 
Morales, L. (1999) 'Political participation: exploring the gender gap in Spain’, South European Society and Politics, vol. 4, no. 2, pp. 223-247.

Morales, L. (2006) ‘Comportamiento electoral y género: España en perspectiva comparada’, in Mujeres, instituciones y política, eds I. Diz Otero \& M. Lois González, Bellaterra, Barcelona, pp. 47-78.

Osborne, R. (2008) ‘De la “violencia” (de género) a las “cifras de la violencia”: una cuestión política’, Empiria, no. 15, pp. 99-124.

Osborne, R. (2009) Apuntes sobre la violencia de género, Bellaterra, Barcelona.

Paramio, L. \& Reverte, J.M. (1980) ‘Contra las cuerdas’, in Crisis de los partidos políticos, ed F. Claudín, Dédalo, Madrid, pp. 175-198.

Pérez del Río, T. (2007) ‘La ley orgánica de igualdad efectiva entre mujeres y hombres. Aproximación para el debate’, Revista de Derecho Social, no. 37, pp. 223-250.

Pettit, P. (2008) Examen a Zapatero, Temas de Hoy, Madrid.

Prior, M. (forthcoming) 'You either got it or you don't? The stability of political interest over the life cycle’, Journal of Politics.

Uriarte, E. (1997) ‘Pautas de cultura política y participación en España’, in Mujeres en política: análisis y práctica, eds E. Uriarte \& A. Elizondo, Ariel, Barcelona, pp. 182-200.

Valiente, C. (1996) ‘El feminismo institucional en España: el instituto de la mujer, 1983-1994’, Revista Internacional de Sociología, no. 13, pp. 163-204.

van Deth, J.W. (2000) 'Political interest and apathy. The decline of a gender gap?' Acta Politica, vol. 35, no. 3, pp. 247-274.

van Deth, J.W. \& Elff, M. (2000) Politicisation and political interest in Europe: A multi-Level approach, Mannheimer Zentrum für Europäische Sozialforschung, Mannheim. 
Verba, S., Burns, N. \& Schlozman, L. (1997) ‘Knowing and caring about politics: gender and political engagement', Journal of Politics, vol. 59, no. 4, pp. 978-1051.

Verge, T. (2008) ‘Cuotas voluntarias y legales en España: la paridad a examen’, Revista Española de Investigaciones Sociológicas, no. 123, pp. 123-150.

\section{Acknowledgments}

We thank Marta Fraile, Gema García, Álvaro Martínez and Alberto Sanz for their comments. We are also grateful to Bonnie Field and the two anonymous reviewers for their comments on a previous version of this work.

\section{Notes}

${ }^{1}$ El Mundo, 16 April 2006.

${ }^{2}$ On dependency: Law 39/2006, 'Promoción de la Autonomía Personal y Atención a personas en situación de dependencia’, Boletín Oficial del Estado (BOE), no. 299, 15 December 2006. On education: Organic Law 2/2006, ‘Educación’, Boletín Oficial del Estado (BOE), no. 106, 4 May 2006. On violence: Law 1/2004, ‘Medidas de Protección Integral Contra la Violencia de Género’, Boletín Oficial del Estado (BOE), no. 313, 29 December 2004. On equality: Law 3/2007, 'Igualdad Efectiva entre Hombres y Mujeres’, Boletín Oficial del Estado (BOE), no. 71, 23 March 2007.

${ }^{3}$ Junta Electoral Central 5/2007, 12 April 2007.

${ }^{4}$ The Spanish Government has published a number of basic introductory papers on the scope and the functioning of the equality law for the local elections of 2007 and the general elections of 
2008 (Ministerio del Interior 2007, 2008). See also ‘Ley para la Igualdad de Mujeres y

Hombres', Ministerio de Igualdad, available online at

http://www.migualdad.es/mujer/medios/docs/Folleto_Igualdad.pdf

${ }^{5}$ CIS no. 2745 (December 2007).

${ }^{6}$ CIS no. 2630 (December 2005).

${ }^{7}$ The pooled dataset when the dependent variable is interest in politics includes the following CIS surveys: 1788 (January 1989), 2450 (March 2002), 2632 (January 2006) and 2760 (April 2008). When the dependent variable is vote for PSOE versus vote for PP or vote for IU the dataset includes the following CIS surveys: 1788 (January 1989), 2128 (December 1994), 2450 (March 2002), 2602 (April 2005) and 2760 (April 2008). 